\title{
THEORIES, MODELS AND URBAN REALITIES. FROM NEW YORK TO KATHMANDU
}

\author{
Román Rodríguez González \\ Department of Geography. University of Santiago de Compostela (Spain) \\ Pza.Universidade s/n. I5.78I. Santiago de Compostela. Spain \\ e-mail: xeroman@usc.es \\ José Somoza Medina \\ Department of Geography. University of León (Spain) \\ Campus de Vegazana s/n. 2407I. León. Spain \\ e-mail: dgejsm@unileon.es
}

\begin{abstract}
At the beginning of the 21 st century, there are various social theories that speak of global changes in the history of human civilization. Urban models have been through obvious changes throughout the last century according to the important transformation that are proposed by previous general theories. Nevertheless global diversity contradicts the generalization of these theories and models. From our own simple observations and reflections we arrive at conclusions that distance themselves from the prevailing theory of our civilized world. New York, Delhi, Salvador de Bahia, Bruges, Paris, Cartagena de Indias or Kathmandu still have more internal differences than similarities.
\end{abstract}

Key words: Urban models, social theories, globalization and cities

\section{THEORIES}

The industrial society in the XIX and XX centuries established a model of accumulative growth in cities that seems to have lost its significance in the last years. It does not mean that urban population growth stopped, because every day there are more people living in cities, but the traditional model is unable to explain the current situation.

The "net society" promotes the decentralization of the human activities, in such a way that the basis of the urban growth, the economies of scale and the concentration of the factors of production, lose their validity at the beginning of the XXI century. This premise is particularly true in the most developed economies of the planet, but it is more difficult to look for postmodern elements in Nepal, to give an example. In fact, as it happened at the 
end of the XVIII century, when the change began in just a few innovative spaces and later went expanding slowly to other places, nowadays, the situations of cities is not the same everywhere, and the reasons that allow us to explain why Barcelona (Spain) loses population between 1980 and 2000 (the city and the urban area), is opposed to the factors that determine the growth of Lagos (Nigeria), during the same period. This historical comparison implies an added singularity, when the first factories started to move the world from England, the societies of the planet could be defined, more or less, with some common characteristics. Up to now, the change of a society model to another one had taken place along centuries of slow transformations. However, the transition from the industrial society to the "net society", or to use other terms and theoretical models to "the Global Village", "the Third Wave", "the scientific-technological revolution", "the Electronic Era" or "the Postmodern Society", has taken place in hardly two centuries in England, a hundred years in Japan, fifty in Spain and twenty in Brazil. But, what happens with the countries that have not yet experienced the industrialization?. Are they able to jump a historical phase in the evolution of humanity generating similar places? Is it feasible to move from the oral transmission to internet without going by the book?

In this paper we have carried out a comparative exercise on the transformations that the globalization process has motivated in territorial, socioeconomic, political and cultural differentiated contexts. From the western societies it is insisted on employing theoretical models that define urban networks in a global scale, determined by thousands of connections of visible and invisible flows, where the World Cities exercise as capital nodes of decision making. However, these global theories hide diverse and easily perceivable realities that force us to question the validity of generic patterns, even now when the broadcasting of a soccer match is able to bring together hundreds of million of people all over the world in front of the television screens, in real time.

In 1968 Doxiadis had a then innovative theory on the future of human settlements. This Greek architect postulated that urban life would be imposed on all human territory generating population structures that would accumulate until they reached the pinnacle of a pyramid forming a single world city, the ecumenopolis, made up of hundreds of megalopolis.

The same year that the concept of ekistics was born, Marshall McLuhan theorized on the cultural revolution that could generate the development of communication systems. This lead to the idea of a Global Village where we would all share the same ideals, dreams, likes, and hobbies. It would be a uniform culture that throughout time would generate the same type of city throughout the world with buildings, streets, plazas, malls, and public parks all sharing the same channels of communication.

In 1980 Alvin Toffler published "Third Wave", one of his best known works where he explained his theory of evolution in three waves. The first wave begins with agricultural development, where man is no longer required to constantly move in search of food, and he can settle to cultivate the land. Land is the key element in this phase. The second wave arrives in the $18^{\text {th }}$ century with the invention of machines. The population abandons their agricultural way of life and moves to the cities to work in the new factories. The power that previously came from owning land now comes from three elements - land, workforce, and 
capital. Goods are produced in assembly lines and en masse to reduce expenses allowing the same product to be commercialized in every corner of the earth. The third wave begins to appear after World War II when education becomes universal and the individual is more important than the community. It is no longer important to use assembly lines or produce en masse. Technology and individualized products become more important. We go from the store that produces the same thing in 10,000 places to the store that produces 10,000 different things in the same place. We arrive at a knowledgeable society where information is power. It is a new wave that is also characterized by a different model of human settlement. The cities are abandoned and residential space is sought far from the cities.

Finally, Manuel Castells has used the concept Net-Society in his last books to make reference to the new social model that we find ourselves in at the beginning of the $21^{\text {st }}$ century where all our activities are inter-related through various tangible and intangible flows and that what happens in any one point can have immediate repercussions in another place thousands of miles away. The internet is the new tool of the future. If previously we said that information was power what is now true is that this power has never been more within our reach.

As we now see, there are different theories that definitely highlight the changes that have been produced in human evolution since the middle of the $20^{\text {th }}$ century. There has been a transformation in our way of life that is reflected in the cities in which we now live.

\section{MODELS}

Since the twenties when the Urban Ecological School of Chicago created their first analytical models of the city, many social researchers tried to draw on paper the impossible: to reduce the complexity and diversity of the city to just one unique model.

E. W. Burgess outlined the competence amongst the different human groups vying for the best urban ground suitable for their interests and he defined a model of concentric rings representing a concrete reality - Chicago in the 20s. The Loop was surrounded by factories that also bordered the suburbs of less developed areas like ghettos, Little Sicily, and immigrant neighborhoods. The farther you move from these places the better the homes and economic level of the inhabitants are until you arrive to the urban limit where you only have isolated houses and bungalows used by commuters. This gradual transition allowed researchers to establish a theory about the urban ecology and provide a model so general that it should be repeated everywhere.

Years later, Burgess' model was modified by other authors like H. Hoyt or C.D. Harris and E. Ullman. The first one created a model of sectors where the same categories as the School of Chicago were repeated. The only difference was that when you study 142 cities in North America it is impossible to maintain the regularities of these concentric rings making it more probable that populations of different socio-economic levels were joined by sectors. At the same time there was a new reality in relation to the Chicago of the last decade where there is progressive movement of industrial factories to urban peripheries. $\mathrm{H}$. Ullman published his research some years later and his Nucleus Model reflected the evident 
changes in the North American city in relation with the last two models. His changes included the first residential suburbs, industrial areas or the creation of new business areas far from the traditional CBD.

Some authors tried to move these models into their urban realities and they found that they had to modify the original approach. P. Mann, for example, in his essay on British cities made up a model integrating the last three visions. He divided the urban space in concentric rings, sectors and isolated nuclei (Pacione, 2001)

In the most recent phase, new forms of human settlement are also represented through models, and with this in 1996 Graham and Marvin published their graphic conceptualization of global cities in post-industrial time. It was a wide and irregular space where different malls, border cities, subcenters and suburbs were located around the Global Command Centre CBD, and so breaking the classic scheme of the compact city.

This fragmentation of the city is more clearly appreciated in the two recent models in figure 1. In the first one, Dear and Flusty perceive the new urbanism with the concept of "Keno" capitalism, that is, a postmodern urban structure where the discontiguous space is configured as a specialized collage made up of border cities, corporate citadel, ethnourbs, theme parks, places for leisure and entertainment, closed communities, malls, restraint areas, centers of control and urban guerrillas. All these parts of the city are connected by a net of communication systems in such a way that the connecting highways are the streets and avenues. From a similar point of view, L. Ford (in Amendola, 2000) sees the city as a huge theme park, also discontinuous, where the specialized parts of the previous structure take the name of a story, Disney like. In this idea of a city we find: Learningland (University campus), Greenland (urban parks), Apartmentland and Condoland (high and medium-high level suburbs), Gentryland (traditional residential neighborhoods), Conventionland (space for conventions), Yuppieland (Cafes, offices and trade shops), Businessland (skyscrapers area), Governland City (public buildings), etc.

Figure 1. Urban models. (Burgess, 1925; Hoyt, 1939; Harris and Ullman, 1945; Mann, 1965; Graham and Marvin, 1996; Dear and Flusty, 1998; Amendola, 2000)

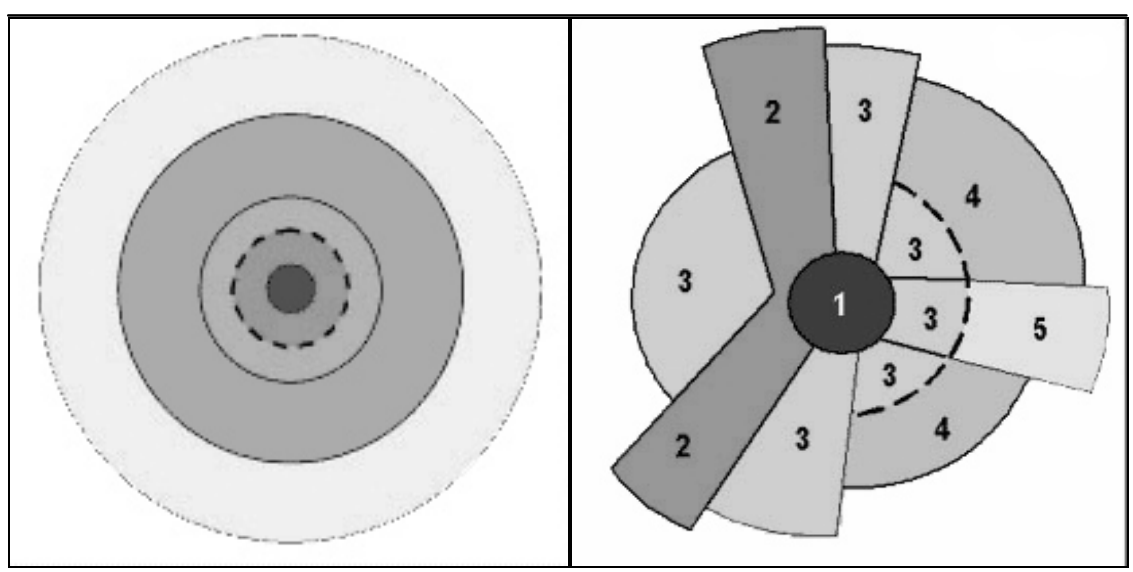




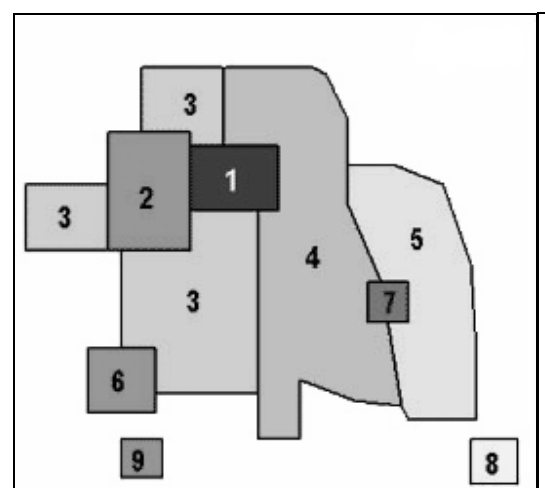

(5)

(5)
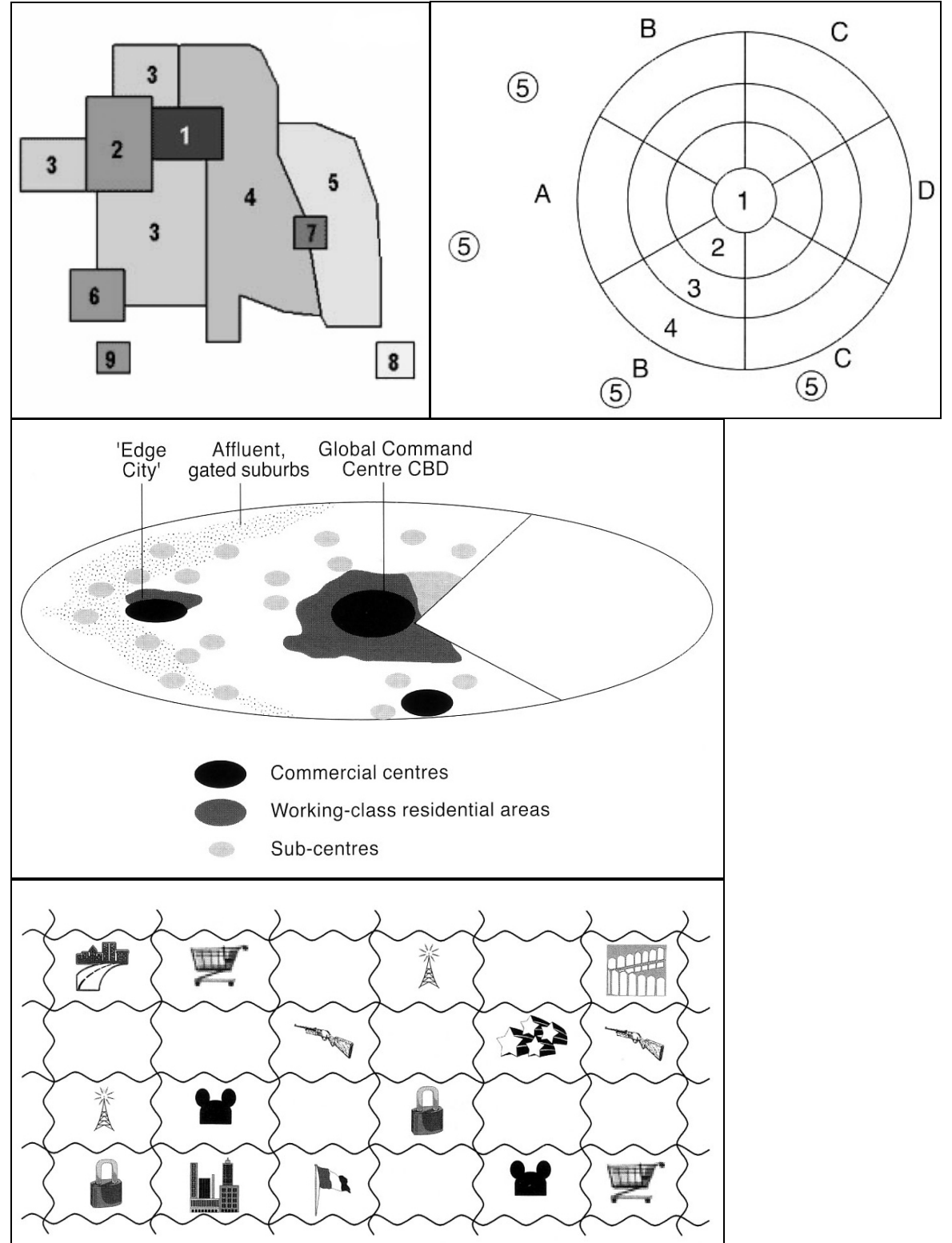

$\begin{array}{ll}\text { DSH/Interdictory Spaces } & \text { Edge Cities } \\ \text { Theme Parks } & \text { Gated Communities }\end{array}$




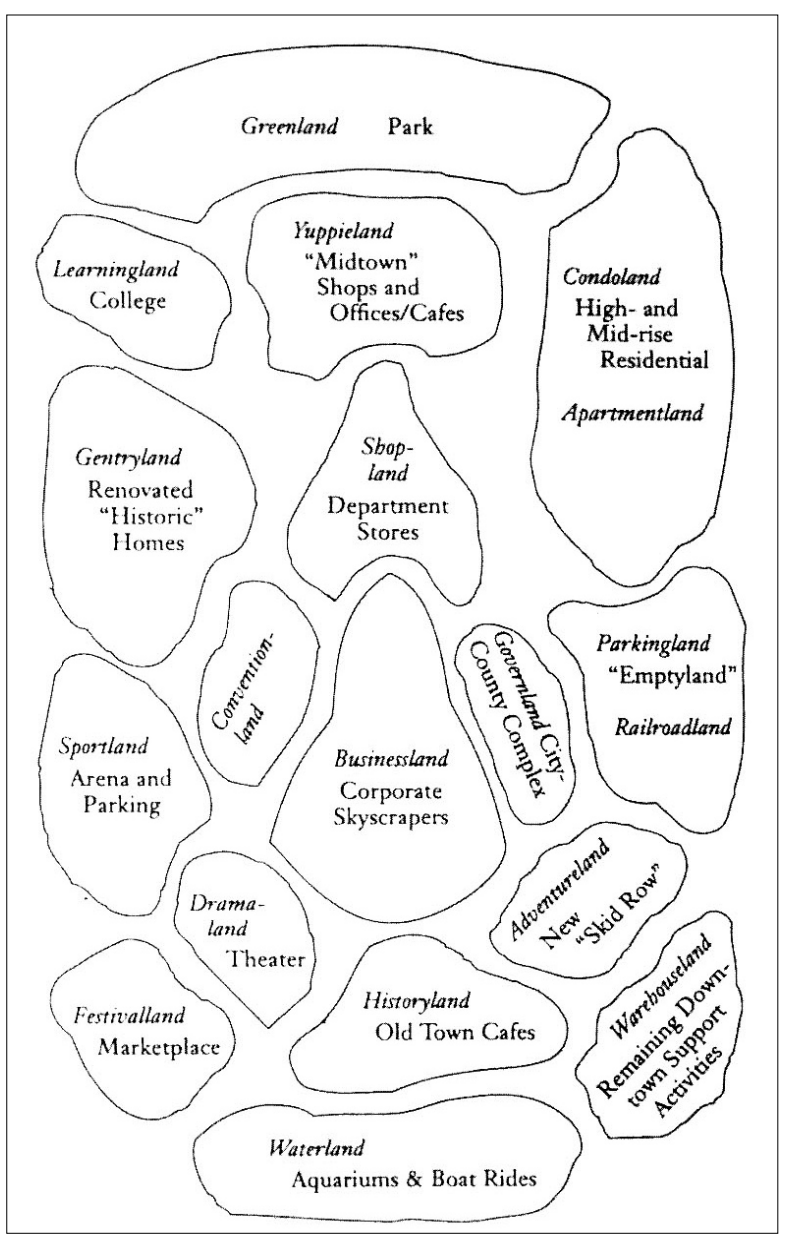

E. Soja in his analysis of Los Angeles as a paradigmatic city ("It all comes together in Los Angeles") individualizes six geographies that are part of the actual urban space. All of these geographies can occur in the same urban space. This author talks about Flexcities (postFord industrial metropoli), Simcities (simulated cities and the theme park), Fractal Cities (dual city for well-living and poor-living), Cosmopolis (global multicultural city), Exopolis (urban sprawl) and Fortress Cities (private city, CIDs)

As Dear and Flusty confirm (1998), urban models since the 20s have been through a deep transformation that can be summarized in one sentence "from Chicago to Los Angeles", although some authors may not agree with this election and deny the theoretic primacy of Los Angeles, proposing instead other cities such as Miami (Nijman, 2000). What is definitely true is that the most common urban models have been built in only one country, trying to reflect the reality of its cities, which although many people may want is still very different from the nuclei of the rest of the world. Other than the models of the United States there are theories about the soviet city, Latin-American city, African city, etc, but when 
talking about urban models in general, with no specific geographic location, we always refer to the United States. Can somebody tell me where the CBD of Seville, or Salvador de Bahia, or Rabat is?

\section{URBAN REALITIES}

The city, seen as a human product, is the physical and architectonic reflection of the society that created it. Because of this it is possible to have discussions related to the economic interests and bases that participated in its construction with relation to the system of collective and social values that are prevalent in a given moment, as well as the current political model.

Never during the history of the humankind has a unitary discourse or model existed about the city. The Christian city in the Middle Ages was different from the Islamic city. Pre-Columbian urban models were not only different amongst them but also different from the new cities founded by Spaniards. Even the ancient cities of the Hellenic and Roman Empires were based on different presumptions as compared to other large civilizations of ancient times. In summary, this huge differentiation can be explained if we consider the particular circumstances of each historical period, construction methods, organizational concepts of the society relocating to the urban plan, or the priorities of those who led the city combined with the characteristics of the large regional territories in the world.

As previously stated, today's theories of the urban world state that the $20^{\text {th }}$ century provided the true definition of things urban in such a way that we assume they will continue in the $21^{\text {st }}$ century. On a world scale we see a world of cities, large megalopolis connected by new and powerful communication systems. Their potential to lead is clear in every aspect. That is because in this net-like system important economic and political decisions can be made that affect the whole population of the earth. Behavioral tendencies and a system of collective values are given which become reference points for people who are not living in these big cities to imitate in every possible way. The main traditional cities from the Western world that follow this are Paris, New York, London, etc or from Latin America cities such as Sao Paulo, Lima, Mexico D.F., ... At the same time other settlements such as Lagos, Calcutta or Delhi join this ranking of large urban conglomerates.

Nevertheless this complex world of mega cities presents several internal differences. One thing that could place them in the same group is the fact that they have a dense population. The rest of the explaining facts show that the differences are bigger than the similarities. Among those groups, the inequalities related to the level of socio-economic development affecting the elements associated with the quality of life (services, infrastructures, employment, architectural and residential typology, ...) is abysmal. From here we have a panorama where from a compared geographic standpoint, we need to reflect several questions that one way or another will allow us to understand the city of tomorrow: What is it?, How is it built and who intervenes in its process? Or, How many "cities" are inside each one and how do they organize themselves? 
Fotograph 1. Different cities, different urban models: Delhi; Hamburg, Kathmandu, Paris, Rabat, New York, Salvador de Bahía, Berlin, Sao Paulo, Bogotá (Photographs by the authors).
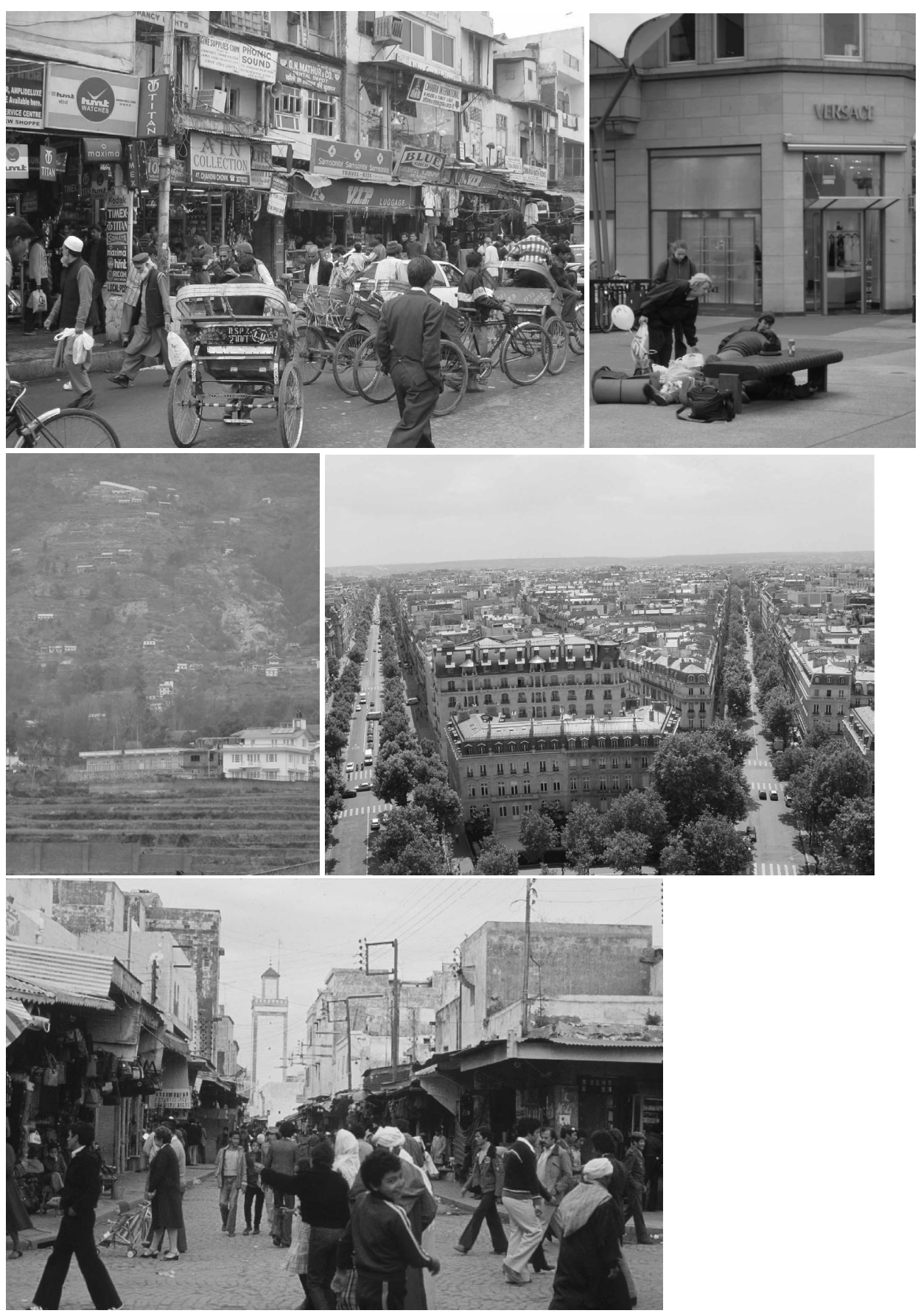

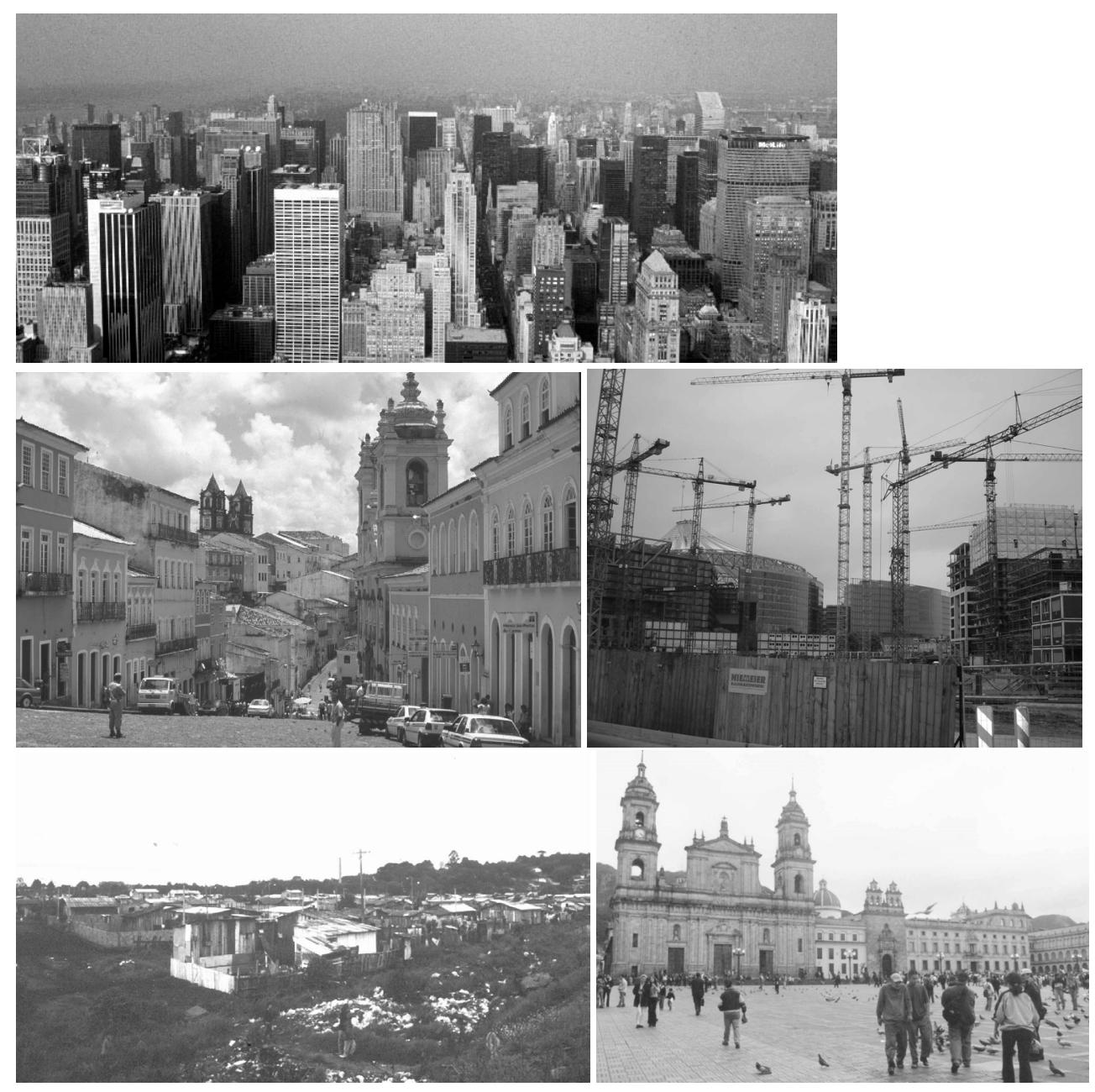

In todays-urban context the classical definitions of a city get diluted and lose interpretative power. This is due not only to the large expansion of the urban fact that sometimes makes difficult to mark a difference among rural territories, but also to the fact that many of the socio-economic and physical architectural characteristics that individualize them get lost, or at least, differ from their traditional image. As an example, one important defining element is the association with the human concentration density and to the predominance of jobs related to industry and services. Actually this last activity is the main urban activity once the pure functional industry lost importance in the majority of the nuclei. The main cities of the world are made up of large centers where goods, ideas, and finances are exchanged; tourist and entertainment centers where a specialized third sector is the main referent. The change in space is the creation of urban sectors with tall buildings, headquarters of business corporations, that become the symbols of the city and true places of employment: the "city" of London, Manhattan, La Defense, ... 
Related to the definition of services, the big cities of the third world also count on an important third sector. Nevertheless, the differences and contradictions are very clear. Personal services and business, not taking into account some shopping imported from the Anglo-Saxon culture, have an informal and basic character with an apparent disorganization, whose main objective is survival of the individual. This is clear in cities such as Delhi or in the neighborhoods of Latin American cities.

In this case the city is a huge crowd of people, most of them unemployed or with informal employment, within a social model characterized by marginalization and poverty, living in big districts called "favelas" or "ranchitos", without any kind of infrastructure or urban services.

Social and functional segregation have always played an important role in the construction of a city. Today's cities are structured beginning with the addition of some sectors specialized in different uses: residential, commercial, industrial, leisure ..., connected by powerful systems of transportation. This situation arises from the growth of today's city and the attempt to expand the urban space with the purpose of introducing new parameters for quality of life and efficiency in its daily occurences. A new urban model appears, AngloSaxon like and with its main examples being cities in North America, organized around a central C.B.D., with residential suburbs and production or service areas specialized in different functions: leisure, sports, ... This urban concept has been expanded to the Anglo Saxon cultural circuit and to Latin America, while the model of a compact and diversified city, Mediterranean like, is losing ground in direct relation to the growth and expansion of the city itself. Expenses of relocation, traffic jams, or segregations due to high prices in residential land turn this model of a city into something impossible. This conception is kept to a certain urban scale, but when you reach a certain size, you jump into the Anglo Saxon model of specialized internal urban areas.

A symbol of this process of functional specialization is that we very often see large commercial complexes and indoor leisure centers in most cities of the world. These, either downtown or outside the city,account for urban mobility and social relations. Their expansion is associated with the Anglo Saxon model, nevertheless their organization and structure try to imitate on a small scale and in an artificial way the idea of the Mediterranean compact city. One objective of this complex is to reproduce the "plaza", the Greek "agora", in an artificial way inside the specialized city with a large expansion. This is clear in Latin American cities, where colonial centers were replaced in their functions (except for political and religious representations) by "shoppings." These "shoppings" try to reproduce characteristics of the latter sector (walking areas, open shops, and areas for leisure, socialization, and, shopping,...) adapted to certain particularities of the urban reality (easy accessibility by various means of transportation, security, social segregation,...). As a result, public areas, streets and squares are replaced with new closed areas, more secure and built in an artificial way. This means we lose the city as a collective creation, and we also lose its traditional conceptions.

The strengthening of tomorrow's city will be led, we assume, by those motivations derived from large economic and financial consortiums. Throughout history, the city has always developed according to the specific interests of the most powerful agents supervi- 
sing its construction. The origins of urban nuclei are the result of two differentiated concepts that, with some logical modifications, are still valid today and we presume will be in the future. On one side, some settlements emerge spontaneously taking into account the competitive advantages of a concrete location (the facilities to defend itself, central location, good communication systems ...). Nevertheless on the other side we have those settlements that are the result of some well-purposed plan by the "power", especially the political-military and religious organizations, to give way to specific interests. We have plenty of examples of this last concept in the urban geography of the world, since medieval hamlets to the foun-dation of large colonial empires, or in the most recent past, cities like Brasilia or Islamabad.

So it is that in the urban creation two essential initiatives coexist. One answering private interests, promoted by the civil initiative, and another one related to public powers. Both groups of agents start from opposite interests and conceptions as regards to what a city is. For the first one, it is the scene where activities take place, its aim being to reach a certain economic benefit. In the second one the scene is used as both mechanism and symbol to reinforce its leadership. The result is the conjunction of urban models that differ in relation to weft, form and conception. The public city gets strength from the impulse of political powers in thinking that this is a wonderful example of their influence. From Neron, who burnt Roma to rebuild it, to the Napoleonic Paris planned by Baron Haussman, or to the communist Bucharest, we have many examples of profound urban interventions to create a model of the city according to the interests of their governors. Imperialist powers built their colonial cities according to specific plans to imitate their model of political power. That is the case in Spanish cities of South America organized in squares, starting in the "plaza" (square) where all the buildings symbolizing the religious and political-military power were located. This had also happened centuries before in the foundations of the Roman Empire in Western Europe.

As the political power becomes democratic, it loses its capacity to confront the large building plans or the urban renovations (in some examples it shows an excess of authoritarianism). Its leading role is transferred, or at least shared, with the private enterprises that share intervention interests and strategies in the city. The clearest examples are urban operations of cities like Paris, related to the government of F. Miterrand, or those cities that promote huge renewal strategies with the help of some world-range event (Olympics, World Fairs...), cities like Barcelona, Berlin, Sydney, Seville, Seoul... From a historic perspective, in those countries where civic society had a great traditional leadership, for example commercial cities in Northern Europe, or trade cities, the leading role in creating the city has been shared from the very beginning. Public power can also surrender its initiative when it does not have the power and necessary means to control and plan urban growth. This situation is easily identifiable in South American cities where the rare leadership of the State is not even able to establish the guidelines of its own expansion, which moves into the hands of private enterprise.

The clearest examples of contrast between public and private cities can be the differences that exist in the urban configuration of cities like Paris or Berlin, if we compare them with other cities like London or New York. In the first one, we see the city as something starting from big public interventions structuring its site (avenues, big squares, symbolic 
buildings with public character...), while in the second one (especially in the neighborhoods of the "City" or Manhattan), the urban site does not have an external reading. On the contrary, its morphology answers to a logic of advantages and economic profitability, with no outdoor public areas, a large concentration of buildings, where the architectonic referents here are associated with big real estate, sites of business corporations, and there is a chaos, evident in the City, as far as styles and architecture are concerned. The private city also shows itself in those States where the administration's weakness makes it more difficult to start the collective processes of urban expansion. We find clear examples in cities of Brazil where, with the exception of the Brazilian sector planned by O. Niemeyer, the recent urban growth has been characterized by the inability of the public power to focus and organize its expansion. Its image is the proliferation of an urban space where marginal districts of "favelas" mix randomly with large residential or tertiary-use buildings, closed malls or even historic places with a colonial origin, with no apparent rationality. In the urban crowds of the Third World, it is even more obvious, demonstrated by the incapacity of the Administration to create the minimum infrastructure and offer urban services, that practically do not exist. Cities like Delhi, Kathmandu, Lagos or any other similar city have millions of people living under a situation of great precariousness.

The city of tomorrow will answer one of the big questions related to its internal structure. Inner segregation, derived not only from the different uses and functions of the city, but also from the economic level of their citizens, will be each time more evident. Even in the social models sustained by false equalitarian ideologies, with a soviet influence that has disappeared or is still alive, the urban differentiation has been retained as an identity sign difficult to eradicate. Consumption and enjoyment of urban sites will introduce new models of separation. Apart from the traditional uses of urban separation (zones for industry, sports, residential areas...) the cities gain more and more importance as a tourist destination, and this allows the introduction of new parameters of inner organization. This situation is clearly seen in the strengthening of well-thought and organized sectors for the intended use and enjoyment of tourists. This process happens in the First World cities (almost all in the historic part of some European cities now turned into real cultural thematic areas), but also in those less developed cities where genuine "islands" emerge inside the city (Kathmandu if we think of mountain tourism, Caribbean cities...).

Finally, cities in the $21^{\text {st }}$ century have a tendency to convert themselves into an area of both mixture and segregation of different races and ethnic groups. Here contradictions are related to the disparities in their development. In cities such as Los Angeles, New York, London or Amsterdam, the racial mixture is enormous, creating the difference between politics of assimilation or the fostering of multiculturalism, following the theory of the melting pot. On the European Continent a significant part of the inhabitants with "aloctonas" racial characteristics are descendents of the privileged social sectors of the old colonies, coming from the old local elites, and so they keep a great cultural adaptation compared to the old metropolis. In those countries with a lesser degree of development, we can also identify cities formed by several differentiated collectives. Numerous Latin American cities where descendents of European people, black African slaves, or natives live together are direct examples of this situation. A great example of this situation could be Salvador de 
Bahia, where several ethnic groups live together. They point to a social segregation associating the social origin of each person to the role they have in society, keeping a clear model of ethno-socio-economic differentiation that makes relative the multicultural concept of the city.

To conclude, the city of tomorrow begins with a historic and socio-economic analysis that in large part indicate the urban development of each location. The contrasts and contradictions around human progress in each society move to the urban world, creating a wide range of possibilities among the cities according to their role in the urban world net. At the same time, the city of tomorrow will also be characterized by the collaboration between private enterprises and the role of public entities. They will have to focus on urban expansion derived from a global economic model which fosters excellence, competitiveness, and the configuration of large business conglomerates, whose importance at the time of creating a city is each time more prominent.

\section{References}

Amendola, G., 2000: La ciudad postmoderna. Madrid. Celeste.

Burgess, E., 1925: The growth of the city. V: Park, R., Burgess, E. (editors). The City. Chicago. Chicago University Press.

Castells, M., 1996: La era de la información. Vol 1. La sociedad red. Barcelona, Alianza.

Dear, M., Flusty, S., 1998: Postmodern Urbanism. Annals of the Association of American Geographers, 88 (1), p. 50-72

Doxiadis, C. A. 1968: Ekistics. An introduction to the science of Human Settlements. New York, Oxford University Press

Graham, S., Marvin, S., 1996: Telecommunications and the City. Electronic Spaces, Urban Places. London, Routledge.

Harris, C., Ullman, E., 1945: The nature of cities. Annals of the American Academy of Political Science, 242, p. 7-17

Hoyt, H., 1939: The Structure and Growth of Residential Neighbourhoods in American Cities. Washington D.C. Federal Housing Administration.

Mann, P., 1965: An approach to Urban Sociology. London, Routledge.

McLuhan, M., 1968: War and Peace in The Global Village. New York, Bantam.

Nijman, J., 2000: The Paradigmatic City. Annals of the Association of American Geographers, 90 (1), p. 135-145

Pacione, M., 2001: Models of Urban Land Use Structure in Cities of the Developed World. Geography, 86 (2), p. 97-119

Soja, E., 2000: Postmetropolis. Critical studies of Cities and Regions. London, Blackwell.

Toffler, A., 1980: The Third Wave. New York, Bantam 